\title{
An Inquiry into the Promise and Prospects of Smart Growth
}

Draft Date: August 27, 2002

\author{
Gerrit-Jan Knaap \\ Director of Research \\ National Center for Smart Growth Education and Research \\ University of Maryland \\ gknaap@ursp.umd.edu
}

Prepared for Presentation at the International Workshop on Urban Growth Management:

New Approaches to Land Management for Sustainable Urban Regions

University of Tokyo, Tokyo, Japan, 29-31 October 2001

For discussion only; do not quote 


\section{An Inquiry into the Promise and Prospects of Smart Growth}

Smart growth is a term rising rapidly in use and ambiguity. The origin of the term is uncertain, though some credit Harriet Tregoning, former Director of the Development, Community and Environmental Division of the U.S. Environmental Protection Agency (USEPA) and now the smart growth Czar in the cabinet of Maryland's Governor Glendening. Even if fiction, this story has a certain allure, since the USEPA and the State of Maryland have done much to make smart growth an agenda item of many states, local governments, and interest groups. Despite its popularity, however, the concept of smart growth remains ephemeral. Much has been written about smart growth in the popular press and newsletters of advocacy organizations, both pro and con, but little has been written about it in the academic literature (early contributions include Burchell et al. 2000, Downs 2001, and Nelson 2001). As the newly appointed Director of Research for the National Center for Smart Growth Research and Education at the University of Maryland, it will be my job to do just that -- not just with papers of my own, but with papers written by scholars with a variety of disciplinary backgrounds. This paper, therefore, represents a first step towards that end. But my goals for this paper are more ambitious; they include the articulation of an agenda for research on smart growth. This is a formidable task, since the ambiguity of the term leaves little in the realm of land use to eliminate as beyond the scope of the subject. To narrow my scope, therefore, I ignore

all discussions about what constitutes urban sprawl and whether sprawl, however defined, is good or bad. Instead, I focus my analysis on smart growth policies adopted by the State of Maryland.

The reasons for focusing my comments on policies adopted in Maryland are obvious. Maryland is frequently promoted as the exemplary smart growth State and will soon pay my salary. Unfortunately, Maryland's smart growth policies are relatively new, some less than five years old; hence there is little information available on the intended and unintended effects of these programs. Since they were adopted only a short four years 
ago, insufficient time has elapsed to permit even a preliminary assessment. Thus, policy analysis of Maryland's smart growth program is probably premature. ${ }^{1}$

Though innovative and unique, Maryland's smart growth policies were not established in a vacuum. Instead, they extend a long history of land use planning and management and share structural similarities with programs in a variety of policy areas. One of Maryland's most innovative policy instruments, priority funding areas (PFAs), for example, combines the objectives of urban growth boundaries (UGBs) with an infrastructure subsidy program that is spatially defined. Thus, the literature on UGBs and spatially defined subsidy programs -- such as tax increment finance districts and special service districts -- ought to provide some insight into how PFAs might work, how they might fail, and how best to monitor their success. Similarly, the Rural Legacy Program extends a history of experimentation with purchase and transfer of development rights. Thus, though new and unique, each of Maryland's smart growth strategies has historical and structural antecedents, a review of which might provide considerable insight into the prospects for successful smart growth.

In Maryland, "Smart Growth" refers to a bundle of growth management programs passed by the Maryland State legislature in late 1997. Maryland's Smart Growth legislation includes:

- Priority Funding Areas: A program in which State subsidies for new roads, water, and other infrastructure are available only for projects that are either within municipalities, within the I-495 and I-695 beltways, or within other areas that meet certain criteria;

- Rural Legacy: A program in which the State provides funds for local governments and land trusts to purchase properties and development rights in rural areas to preserve agriculture, forest, and natural resource lands in contiguous blocks, corridors, or greenways;

\footnotetext{
${ }^{1}$ There have been some preliminary assessments, see 1000 Friends of Maryland 2001.
} 
- Voluntary Cleanup or Brownfields: A program that provides financial incentives and technical assistance to eligible participants in the clean up and redevelopment of underutilized or abandoned industrial properties that are, or are perceived to be, contaminated;

- Live Near Your Work (LNYW): A program that promotes linkages between employers and nearby communities by offering incentives to enable employees to buy homes in proximity to their workplace; and

- Job Creation Tax Credits (JCTC): A program in which employers that create 25 or more new, full-time jobs within a Priority Funding area are eligible for State income tax credits.

In the sections that follow, I will provide more information about each of these policy initiatives, identify historical antecedents, review literature on the effects of those antecedents, and consider the implications history holds for the success and successful evaluation of each smart growth policy.

\section{The History of Smart Growth in Maryland ${ }^{2}$}

Like the growth management programs of all other states, Maryland's smart growth programs reflect the geographic, political, and historic features of land use issues in the State. Maryland is a small, highly urbanized State. Its landscape features the rapidly growing suburbs of Baltimore and Washington, D.C., forested mountainsides in the west, the Atlantic shoreline in the east, and the Chesapeake Bay in the middle. The conflicts that stem from suburban encroachment on Maryland's sensitive environments have long served as the impetus for efforts to manage urban growth. These conflicts are longstanding, pervasive, and not likely to abate in the foreseeable future.

\footnotetext{
2 This section draws heavily on Cohen (2001).
} 
Though the historical roots of Maryland's smart growth program date to 1933, when Maryland established the nation's first State Planning Commission, recent history begins with the formation of the Chesapeake Bay Commission in 1980. This Commission, established to "improve interstate coordination of baywide management," originally included only Maryland and Virginia, but subsequently expanded to include Pennsylvania, the District of Columbia, and the USEPA. An alarming report on the state of the bay issued by the USEPA in 1983 motivated the Commission to adopt the 1985 Chesapeake Bay Restoration and Protection Plan, which committed its signatories to a set of goals aimed at "reducing nutrients, reducing toxins, protecting living resources, focusing environmental programs on Bay impacts, and establishing cooperation among institutions." The plan also required that these goals become linked to state environmental programs. The 1983 report also motivated the State of Maryland to adopt the Critical Area Act in 1984. This Act requires local governments to adopt land use and performance standards within a buffer zone measured 1000 feet from the Bay and its major tributaries (about 10 percent of the State's land area).

In 1987, the Chesapeake Bay agreement was amended to provide more specific goals for the region. Further, the 1987 amendment called for the "commission of a panel of experts to report, by December 1988, on the anticipated population growth and land development patterns in the Bay region through the year 2020; the infrastructure requirements necessary to serve growth and development; environmental programs needed to improve Bay resources while accommodating growth; and alternative mechanisms for financing government services and environmental standards." The panel presented its report, Population Growth and Development in the Chesapeake Watershed to the Year 2020, in December 1988. The report expressed dismay at the lack of growth management and planning, particularly at the State and regional level. It further presented six "visions" for guiding urban development policy in the region.

- Development is concentrated in suitable areas.

- Sensitive areas are protected.

- Growth is directed to existing population centers and resources are protected. 
- Stewardship of the Bay and land is a universal ethic.

- Conservation of resources, including a reduction in resource consumption, is practiced throughout the region.

- Funding mechanisms are in place to achieve these visions.

According to DeGrove (forthcoming), "this report has proven to be a key document in the still unfolding history of growth management in Maryland."

Then Governor William Schaefer responded to the report by appointing the Governor's Commission on Growth in the Chesapeake Bay Region. The Commission was directed to review the findings of the 2020 panel, determine their application to Maryland, identify growth issues the State should address by the year 2020, and make specific recommendations for steps that Maryland should make to improve environmental quality while maintaining a healthy state economy. Chaired by former Maryland Congressman Michael Barnes, the Commission became known as the Barnes Commission. The Barnes commission presented its report, Protecting the Future: A vision for Maryland, in 1991, and legislation based on the report was introduced as the 1991 legislative session convened. For a variety of reasons, however, the legislation proposed by the Barnes Commission never made it out of Committee. It did, however, provide the foundations for the Maryland Economic Growth, Resource Protection and Planning Act of 1992.

The Planning Act of 1992 required local governments to prepare comprehensive land use plans, to incorporate each of the six visions and a sensitive-areas element in their plans, to encourage economic growth and regulatory streamlining, and to review their plans every six years. Once a plan is adopted, local governments may approve development projects that include State funds only if they are consistent with the plan. The State also may not fund a public works or transportation project unless the project is consistent with the applicable local plan. The Maryland Department of Planning must provide written commentary on the sensitive elements of all plans, but local governments need not incorporate the State's recommendations in their plans. It also established a 17-member Growth Commission to advise the Governor on progress toward the six visions. 
Although the 1992 Planning Act provided a framework for including the previously articulated visions into local comprehensive plans, it lacked specificity on several matters. In its 1996 annual report, the Growth Commission asserted that the 1992 Act did not adequately define key phrases, such as concentrated or suitable growth in Vision 1, and critical masses for farm and forest land and non-growth areas in Vision 3. Following an extensive listening campaign, many meetings, and frequent forums, the Governor's Office developed the five initiatives (PFAs, Rural Legacy, Voluntary Cleanup, LNYW, and JCTC) that have made Maryland recognized as the undisputed leader in the promotion of smart growth.

\section{Characteristic Features of Maryland's Approach to Smart Growth}

Maryland's smart growth programs are innovative and interesting in a number of ways. From the outset, Governor Glendening sought to develop a strategy that:

- Favored incentives over regulations;

- Preserved local autonomy;

- Could be rapidly implemented;

- Would not create a new bureaucracy; and

- Had modest budgetary impacts.

For the most part, the five smart growth initiatives meet these requirements. Planning and development regulation remains primarily under the domain of local governments. There is no State land use plan. The Department of Planning, and its budget, already existed; hence no new agency was needed. Further, the administration of the programs was assigned to different State agencies: the PFA Program to the Department of Planning; the Rural Legacy Program to the Department of Agriculture; the Brownfields Redevelopment and Voluntary Cleanup Program (VCP) to the Department of Business and Economic Development (DBED) and the Maryland Department of the Environment (MDE); the LNYW Program to the Department of Housing and Community 
Development (DCHD); and the JCTC Program to the DBED. Such assignment of programs to multiple agencies not only saved costs, but also built widespread support within state government. The obstacles to implementation created by this distributed form of administrative structure, however, have yet to be explored.

Perhaps the feature that most distinguishes the Maryland approach from its predecessors is its reliance on spatially specific incentives instead of land use regulations. Local governments can grow anywhere they want but State funds for accommodating development are available only within PFAs. Property owners need not clean up and redevelop their properties but grants are available for doing so. Residents can live anywhere but grants are available for purchasing homes near work. Farm and forest land can be developed but development rights can also be sold and transferred to more desirable locations. Business can expand anywhere but tax credits are available for expansion in certain locations. Such reliance on incentives is what enabled these programs to pass the Maryland legislature and what makes them so attractive to other states.

The potential effects of incentive approaches to public policy can best be understood in the framework of microeconomic theory. When faced with the choice between two alternatives, microeconomic theory suggests that the decision about how much to pursue each is determined by the relative benefits and costs of each alternative. Incentives alter relative costs, make the preferred alternative (from a policy perspective) less costly, and encourage that choice. How much choice is altered depends on the size of the incentives available and the underlying preferences for the two choices.

Using PFAs as an example, the elimination of State funding for development outside PFAs raises the cost of development outside such areas and (perhaps) lowers the cost of development within. In most circumstances, local governments would choose to permit more development within PFAs and less outside such areas. While the analytics of the incentive approach are perhaps simple, they highlight two important features. First, unless the incentives are extremely strong, it is likely that development will continue 
outside of PFAs. Second, if local governments strongly prefer to develop outside preferred funding areas, the incentives might have little or no effect. It is important to recognize that these possibilities are what distinguish incentive from regulatory programs.

\section{Priority Funding Areas}

PFAs are perhaps the centerpiece and most innovative of the Maryland smart growth programs. The PFA legislation builds on the "visions" adopted as State policy in the 1992 Planning Act, especially Vision 1 (development is concentrated in suitable areas) and Vision 6 (funding mechanisms are in place to achieve these visions). The 1997 Smart Growth Areas Act restricts State spending on infrastructure and other growth related expenditures to areas specifically designated for urban growth. PFAs include existing communities and other locally designated areas where State and local governments want to encourage and support urban growth. PFAs automatically include the traditional urban areas of the State: Baltimore City, areas inside the Baltimore and Washington beltways, neighborhoods that have been designated by the Maryland DHCD for revitalization, Enterprise Zones, and Heritage areas.

PFAs also include areas designated by counties outside traditional urban areas, but the designation must be based on an analysis that determines the capacity of land available for development and the land area that will be necessary to satisfy demand for development. ${ }^{3}$ Counties may designate existing communities and areas where economic development is desired. In addition, counties may designate areas planned for new residential development. Areas eligible for county designation include:

- Areas with industrial zoning;

- Areas with employment as the principal use, and areas that are served by, or planned for service by, a sewer system;

\footnotetext{
${ }^{3}$ The required analyses are similar to those for urban growth boundaries in Oregon. See (Maryland Department of Planning, on line ).
} 
- Existing communities with existing sewer and water services that have an average density of two units per acres;

- Rural villages designated in local comprehensive plans; and

- Other areas that meet specific density and urban service criteria.

While interesting and innovative, PFAs share features with other better-known urban containment instruments -- UGBs and urban service areas (USAs) in particular. UGBs, as used in Oregon, Washington, and other states, are lines drawn around urban areas that delineate where urban growth is allowed to occur within a specified time period. In Oregon, for example, UGBs indicate where urban development will occur for a twentyyear period; all land outside UGBs is zoned for nonurban use. USAs are lines drawn around urban areas that delineate where urban services will be provided. In Lexington, Kentucky, for example, the urban service boundary indicates where urban services will be provided; requests for urban services outside the USA boundary will be denied (Hopkins 2001). Although both types of instruments have been around for quite some time, there has been more research on the efficacy of UGBs than on USAs. Most of the research on UGBs examines the experience in Oregon.

Research on the effects of UGBs offers insights into the prospects for PFAs. To the extent that similarities exist, the Oregon experience with UGBs suggests the following. First, the designation of PFAs will be a long and politically protracted process. Second, PFAs will fail to contain all urban growth. Third, sprawl will continue within PFAs. Fourth, controversy will arise concerning the effects of PFAs on land and housing prices. Fifth, and perhaps most importantly, despite these limitations PFAs will improve the process and quality of land use planning.

PFAs, like UGBs, must be designated by local governments and approved by a State agency. As a result, the experience with UGBs in Oregon suggests, conflicts will arise between the State agency and local governments. Politics that play at the local level differ from those that play at the state level (Knaap and Nelson 1992). As a result, local governments will try to include within PFAs more land than the State agency would 
desire. This is even more likely for PFAs, because PFAs delineate areas eligible for State infrastructure subsidies, not areas for which local governments must finance infrastructure from local funds. Achieving compromise between State and local governments will thus take longer than expected. Further, the process for PFA expansion, much like UGBs, has not yet been adequately prescribed. Thus, reaching compromise on the process of expansion will be similarly controversial and protracted. The end result will be an intricate set of rules and regulations that reflect the scars of political compromise more than the logic of land use planning.

Like UGBs, PFAs will leak. That is, development will continue to occur outside the designated areas. ${ }^{4}$ In the case of UGBs, this problem was vexing and unexpected. Because nearly all land outside UGBs is zoned for nonurban use, continued urban development outside the boundaries -- especially in forested and popular recreation areas -- was viewed as a major flaw in the regulatory framework. In the case of PFAs, development outside the boundary is not expressly prohibited and thus should be expected. Urban development outside PFAs is not prohibited, but urban services for such development will not be financed, even in part, with State funds. Urban services outside PFAs, where development pressure is particularly strong, however, can be financed with private or local public funds. Further, according to the microeconomic framework outlined above, it is possible -- even likely -- that local governments will reallocate funds that would have been used to finance urban services inside PFAs to fund urban services outside PFAs. ${ }^{5}$ From the perspective of those who seek to contain urban growth, such behavior is one of the costs of an incentive rather than a regulatory approach.

Like development inside UGBs, development inside PFAs will sprawl unless strong regulatory controls are adopted inside the boundary. One of the most pervasive myths about UGBs in Oregon is that they fit snugly around existing urban development and thus strictly control the location of urban development. In fact, UGBs in Oregon must be drawn to contain a 20-year land supply and be readjusted every five years (Knaap 2001,

\footnotetext{
${ }^{4}$ For preliminary evidence the PFAs leak, see 1000 Friends of Maryland (2001).

${ }^{5}$ The extent to which they do so will depend on what economists call income and substitution effects. See any microeconomics text.
} 
Knaap and Hopkins 2001). This means that at all times UGBs must contain at least a 15year supply of land. Over the last decade, the population in Portland, which has the most infamous UGB, has grown 50 percent while its land area has grown 30 percent. From a containment perspective, this ratio is better than most cities in the United States, but it is far worse than many proponents of UGBs claim (Benfield et al.). Further, the pattern of urban development, when measured in terms of connectivity, the mixture of land uses, and average lot size, has changed very little (Song and Knaap 2002). Given that the state of Maryland is projected to fund more of the infrastructure needed for development inside PFAs, it is likely that development inside PFAs will continue to sprawl.

PFAs, like UGBs, are likely to stir considerable controversy over their effects on land and housing prices. The price effects of UGBs remain highly disputed. Some argue that UGBs have severely constrained urban land supplies and thus caused severe housing affordability problems throughout the state (Staley and Mildner 1999). Others argue that housing prices in Oregon reflect the capitalization of policy-induced amenities (Nelson 1985, 1986). Still others argue that UGBs have had little effect on housing prices at all (Phillips and Goodstein 2000, Knaap 2001). The resolution of this debate appears far from near. But regardless of the outcome, the debate has its cost. Oregon planners and policy makers must devote considerable attention to this issue at the cost of greater attention to other potentially more pressing issues. In the case of PFAs, this issue may come to dominate policy discussions as well, especially since the expansion of PFAs has yet to be resolved.

Finally, PFAs, like UGBs, will play a major role in framing the process of planning. Governments tend to measure and monitor only what they must. In Oregon, the need to ensure that UGBs contain a 20-year land supply has forced local governments to develop extensive land use data and analytical methods. These data and methods have subsequently been used as the basis for many innovative and pioneering land use plans and strategies. It is likely that PFAs will have similar effects. 


\section{Rural Legacy}

The Rural Legacy Program is the program for which Maryland is perhaps best known. The program is specifically designed to protect agricultural lands and other natural resources from urban development. Building on extensive experience with similar programs in Montgomery and Calvert Counties, the State program provides State funds to local governments for purchasing the development rights (PDR) of large, contiguous tracts of agricultural, forest, and natural areas subject to development pressure. Local governments and private trusts are encouraged to identify rural legacy areas that complement existing land conservation programs. For fiscal years 1998 to 2002, the State Legislature authorized \$23 million in General Obligation Bonds, \$18.3 million of real estate tax revenues for Program Open Space, and \$30 million from the budget of Program Open Space, for a total of $\$ 71.3$ million. Of that total, $\$ 2$ million may be used to leverage an additional $\$ 18.2$ to $\$ 70$ million in zero-coupon bonds to purchase easements. (Maryland Department of Planning on line)

A 2000 amendment to the Rural Legacy Act allows development rights purchased from landowners to be resold to developers for use in PFAs. Fifty percent of the proceeds from transfer of development rights (TDR) sales must be used for capital projects in the county or municipality in which the TDR are used. The other half of the proceeds is returned to the program budget, but must be used for conservation purposes in the same county (Cohen 2001).

To participate in the Rural Legacy Program, local governments, land trusts, or landowners must submit an application that describes the proposed Rural Legacy Area; offers a Rural Legacy Plan; identifies currently protected lands in the area; estimates the level of landowner participation; and provides a budget. Applications are reviewed by a Rural Legacy Board that includes the secretaries of the Departments of Agriculture, Natural Resources, and Planning. As outlined in the Act, the Rural Legacy Board must consider the significance of the agricultural, forestry, and natural resource land proposed 
for protection (including the nature, size, and significance of the proposed area), the degree to which the area is threatened by development, the significance of any historic or archaeological sites in the area, and the economic value of the resources or services proposed for protection. In 2000, there were 25 applications for $\$ 90$ million, of which the board approved 19 applications for $\$ 25$ million.

The historical experience with programs like Maryland's Rural Legacy Program has been decidedly mixed, both in intent and in success. Because Maryland's program allows for the resale of development rights, it includes elements of both a purchase of development rights (PDR) and a TDR program. The concept of TDR was first introduced in New York City in 1916. A zoning ordinance enabled landowners to sell unused air rights to owners of adjacent lots thus allowing the receiving lot to exceed height and setback requirements (Johnson and Madison 1997). Since then, TDR programs have been used for a variety of purposes, including urban redevelopment, historic preservation, open space protection, protection of sensitive areas, and agricultural land preservation (Ziegler 1996). Even among those designed to protect farmland, the elements of the programs vary widely (Machemer 1998). Some are voluntary; others are mandatory. Some have predefined sending and receiving areas; others do not. Some permit the banking of development credits; others do not. Given the extent of variation in program details, similar variation in program efficacy is not a surprise.

PDR programs are easier to administer than TDR programs. According to Daniels (1999), over 150 local governments and 15 states are actively involved in purchasing development rights to farmland. The U.S. Government provided \$36 million for such purposes in the 1996 Farm Bill. PDR programs, for the purpose of farmland preservation, have two interrelated limitations: (1) they must be big to be effective; and (2) big programs are expensive. The need for size is perhaps obvious, but varies across regions. In the Midwest, for example, a viable corn or soybean farms must be over 80 acres in size. Further, for an 80 -acre farm to remain viable, it must be surrounded by complementary land uses and far from incompatible land uses. Hence, purchasing small farms with the intent to preserve farming is futile, except perhaps for truck farming 
operations. Further, if there is significant development pressure, development rights can be as high as $\$ 10,000$ per acre. Needless to say, there are few state and local PDR programs with sufficient capital to save farmland at such prices.

TDR programs are less costly, but far more complicated. The cost savings and complexity stem from the ability to transfer or resell development rights to "receiving" areas. By identifying receiving areas in which development rights can be used, TDR programs create a private market for development rights, and the capacity for local governments to recover costs. Because of their additional complexity, TDR programs have had much less success than PDR programs. Although Montgomery County, Maryland, has preserved over 38,000 acres of farmland through its TDR programs, other jurisdictions with programs of similar age have yet to transfer a single development right. However, even when relatively successful (success being measured in total credits transferred) TDR programs have inherent limitations as a farmland preservation tool. In addition to their administrative and legal complexity, TDR programs are limited by problems in assigning development credits, receiving development credits, thin markets, lack of certainty, and scope (Bae 2000).

The problem of assigning development credits in the sending areas is common to TDR and PDR programs. The question is how many development credits (usually measured in dwelling units) does a farmland owner have the right to sell? In general, the answer to this question is answered by the zoning ordinance. If the farmland is zoned at a ten-acre minimum lot size, then the owner of a ten-acre farm has the right to sell one development credit. This method of assigning development credits, however, raises a number of complex legal questions that TDR programs were designed to mitigate. Legal issues notwithstanding, development credits transferred from sending areas must be converted into development opportunities in receiving areas. A simple conversion strategy allows one dwelling unit from a sending area to convert into one dwelling unit in a receiving area; but such a simple conversion will not allow the TDR program to overcome potential additional constraints in receiving areas, such as constraints on floor area ratios, parking, and building heights. 
The problems in receiving areas, besides issues of conversion, are twofold. First, opposition to increases in density occurs nearly everywhere. The residents of receiving areas are thus just as likely to oppose increases in density as the residents of any other neighborhood. Second, for the development credits to have value they must enable developers to do things they could not otherwise do. Thus, to create value, developers must be able to develop in receiving areas at densities (in number of dwelling units, floor space, or fewer parking spaces) higher than that which would otherwise be allowed. This tends to undermine the logic and credibility of zoning in the receiving areas. If, for example, sound land use planning suggests that densities should be around four units per acre in the receiving area, then allowing developers with TDR to build at higher densities violates sound planning principles. Alternatively, if sound planning principles suggest that densities should be higher than four units per acre, then there is little compelling reason for zoning the receiving area for four units per acres. As a result, zoning in both the sending and receiving areas undermines the validity of the underlying zoning restrictions (Jacobs 1993).

The problem of thin markets is intertwined with those described above. A thin market is one in which there are few transactions. Few transactions occur when the value of the commodity exchanged is low relative to transaction costs. For the reasons described above, TDR transactions are costly. For transactions to occur, the value of the development permit must be high to both the seller and buyer. To make the value of the credits high, the number of credits issued in the sending areas must be low and the densities allowed in the receiving areas, without TDRs, must also be low. Lowering credits in sending areas and densities in receiving areas, however, exacerbates the problems described above.

The problem of thin markets is also created by problems of uncertainty. Uncertainty is experienced by farmland owners and developers due to the uncertain value of development permits. This uncertainty can be reduced by creating a permit banking system, though such banks only transfer the uncertainty of value to the public sector. 
Additional uncertainty is also experienced by the public sector. By creating a market for development permits, local governments establish incentives to transfer development rights from sending areas to receiving areas. But the actual transfer of development rights depends on the voluntary decisions of farmland owners and developers. Once again, this is the advantage of an incentive system. The disadvantage, however, is the lack of certainty regarding the density of development -- especially in the receiving areas. This increases the difficulty of planning for the appropriate level of public infrastructure and services.

Finally, the problem of scope limits the efficacy of TDR programs like it does PDR programs. Although larger areas can be designated as sending areas with a TDR program than with a PDR program, the extent to which landowners will participate in the program remains uncertain and in many places disappointingly low. As with other farmland preservation programs, TDR programs are successful only if they preserve large tracts of land for long periods of time. Relying on voluntary transactions as a means to facilitate such commitments is unlikely to succeed -- even in Maryland.

\section{Brownfields Redevelopment}

Brownfield is a term used to describe underutilized or abandoned sites, usually in the inner city, that need cleaning up before they can be improved or redeveloped. The worst of such sites are listed on the Federal Government's National Priorities List (NPL). As part of the Comprehensive Environmental Response, Compensation, and Liability Act (CERCLA) of 1980 (commonly known as Superfund), the entire chain of owners of properties on this list -- and potentially their advisors, lenders, and investors -- are liable for clean up expenses, even if they were not involved in the discharge of pollutants on the property (Meyer et al. 1995). The program imposed huge clean up burdens and created uncertainty regarding what constitutes clean, how long clean up might take, and who is responsible for clean up expenses. Maryland has 21 sites on the NPL and 400 sites on a State Superfund list. Like many other states, Maryland has hundreds of sites with varying degrees of contamination not on either the State or federal list (Leigh 1994, 
Howland 2002). Maryland's Brownfields program is designed to help clean up these sites. It includes two parts: the VCP administered by the MDE; and the Brownfield Revitalization Incentive Program administered by the DBED.

The objectives of the VCP are to:

- Encourage the investigation of eligible properties with known or perceived contamination;

- Protect public health and the environment where cleanup projects are either needed or underway;

- Accelerate cleanup of eligible properties; and

- Provide predictability and finality of the clean up of eligible properties.

To participate in the VCP, an applicant must provide information about environmental conditions, including contamination of the site, and proposed clean up procedures. If MDE approves the application, the applicant must prepare a detailed response action plan that demonstrates how the clean up will be carried out and that the project meets applicable public health and environmental protection criteria.

Brownfield redevelopment programs are common. Besides the federal programs, over 90 percent of states have established some form of VCP (Anderson 1996, ICF Consulting, Inc. and E.P. Systems Group, Inc. 1999). Many of these programs combine regulatory flexibility and liability relief with financial incentives for redevelopment. Some of these are targeted at specifically designated sites or neighborhoods in which such sites are located. Most state programs are designed to address hazardous materials consistent with CERCLA definitions, but include other hazardous materials as well. Many also offer cleanup standard flexibility, where the standard is based on intended land use. Such flexibility is typically conditioned with institutional controls on future land use. Most states also provide financial assistance to help defray cleanup costs. 
In general, brownfields redevelopment programs have been successful. According to Anderson (1996), over 400 sites have been cleaned up under the Minnesota program since 1988. In a detailed analysis of programs in Massachusetts, Michigan, and Pennsylvania, ICF Consulting, Inc. and E.P. Systems Group, Inc.(1999) found more than 85 percent of projects in these states were mitigated beyond background levels. Based on these results, they conclude that "variable clean up standards appear to help redevelopment of contaminated sites." Further, the relatively high degree to which institutional controls were utilized, "suggests that reductions in property values associated with the corresponding limits on alternative uses are not a serious problem, and that the liability relief that accompanies the limits may stimulate more investment." (p. 6-7). ICF Consulting, Inc. and E.P. Systems Group, Inc. also found that financial incentives were influential and sometimes critical to the success for redevelopment projects. In total, however, the financial incentives made up only a small portion of the clean up costs. In some cases, financial incentives were not used at all. Based on these findings, they conclude "financial incentives should not be viewed as essential to successful redevelopment programs.... And that subsides to VCP eligible projects thus may have been inefficient uses of the limited economic development funds available to cities and states." (p. 7)

The need for financial incentives is also questioned by Howland (2000, 2002). In an analysis of brownfields sales and sale prices in Baltimore before the adoption of Maryland's VCP, Howland found that contaminated sites were sold at a significant price discount and remained on the market for shorter periods than sites with unknown contamination. Based on these results, Howland concludes that the benefits of Maryland's VCP will accrue largely to the owners of contaminated properties, at least in locations with an active market for industrial land. Similar conclusions are reached by Meyer and Lyons (2000), who document the emergence of entrepreneurial firms that specialize in brownfield redevelopment. To facilitate activity by these kinds of firms, they suggest that state and local governments make off-site infrastructure investments to improve the market appeal and value of brownfield sites. 
Despite evidence of success, recent findings suggest that brownfields redevelopment programs have limitations. Brownfield redevelopment is precluded or impeded by more general problems of infill redevelopment. Like uncontaminated redevelopment sites, brownfield sites are often too small and poorly situated for redevelopment purposes (Simons and Iannone 1997). Further, like uncontaminated redevelopment sites, brownfield redevelopment is still viewed as more risky and costly than the development of greenfields at the urban fringe (De Sousa 2000). Finally, many successful brownfield redevelopment projects turn old industrial sites into new, upscale residential sites, thus brownfield redevelopment may have smaller economic development and less favorable distributive effects than intended (Bartsch and Dorfman 2000).

\section{Live Near Your Work.}

The LNYW Program is perhaps the most unusual of the Maryland smart growth programs. The goals of the program are twofold: to increase homeownership rates in targeted urban neighborhoods and to reduce commuting travel. The Maryland DHCD administers the program and accepts requests from local governments to have certain neighborhoods designated for revitalization. Once a neighborhood is designated, the DHCD, the local government, and approved employers participate in program implementation. Employers set eligibility requirements, promote the program to their employees, and provide at least $\$ 1000$ to employees to assist with down payment and closing costs. The local government, in turn, provides $\$ 1000$ to each participating employee. In total, the program provides up to $\$ 3000$ to homebuyers in the selected residential neighborhoods.

According to the authorizing legislation, eligibility for the program is not income conditioned. Further, the state allows local governments to define "near" work. The legislation only requires that the residential location has "a reasonable relationship to the location of the employer." By the end of February 2000, 267 homeowners had purchased a home and 47 employers were participating in the program. 
Though the idea of subsidizing residents to live near their work is perhaps novel, the use of subsidies to promote neighborhood revitalization is not. Homeownership has been a longstanding goal of many federal housing programs, though whether these programs were originally intended to stabilize or revitalize neighborhoods remains in dispute. Rohe et al (2001) review studies that examine the broad social impacts of homeownership. They find strong evidence that homeownership results in greater satisfaction with homes and neighborhoods, more participation in voluntary and political activities, and lower tendencies to move. They find weaker evidence that homeownership leads to increased self esteem, less antisocial behavior, or improved physical health. Haurin et al (2002) review theoretical and empirical research on homeownership and neighborhoods. They find many compelling social science theories that homeownership could have and favorable spillover effects on neighborhoods, but little empirical evidence that it does. Rossi and Weber (1996) find that homeownership provides modest personal and social benefits, largely through life satisfaction, selfesteem, and participation in community organizations. Rohe and Stewert (1996) are more sanguine. Through increases in property maintenance and longer lengths of tenure, they argue, modest changes in homeownership can lead to higher property values and greater neighborhood stability. Van Ryzin and Genn (1999) term the foundation for this approach the neighborhood revitalization hypothesis: "the idea that government housing programs, especially working in partnership with community-based nonprofit organizations, constitute a critical ingredient in the physical and economic rejuvinization of poor urban neighborhoods" (p. 807).

The extent to which government can alter residential location decisions remains a relatively unexplored question -- sort of. An extremely large body of literature addresses the spatial structure of urban areas and is founded on the theory that residents trade housing for transportation costs when making location decisions. Residents located near employment centers pay higher housing costs while residents located farther away pay higher transportation costs. Though the results of empirical analysis differ, they generally support the proposition that housing costs do affect location decisions as 
economic theory suggests. Whether a home-purchase subsidy can alter commuting patterns, however, remains unexplored.

\section{Job Creation Tax Credit}

The JCTC Program is perhaps the least novel of the smart growth programs. Passed as an amendment in 1997 to Maryland's existing JCTC program, the new program provides income tax credits to business owners who create at least 25 jobs in PFAs. The jobs must be full time, permanent (with a three-year refund clause), and pay at least 150 percent of the minimum wage. Jobs created after December 31, 1996, must be newly created in a single Maryland jurisdiction. The program is administered by the Maryland DBED.

The JCTC Program is limited to specific industries: economic base; and high-tech industries. Eligible industries include biotechnology, research development or testing, computer programming, data processing or other computer related services, transportation, and communications. To participate in the program, a firm must submit an application to the DBED informing the Department of its intention to use the credits before any qualified jobs are created. The firm's tax credit cannot exceed 1 million per year. As of June 30, 1999, DBED received 123 applications to create 28,000 eligible jobs.

Many states offer job tax credits though program details vary widely. State programs vary in eligible industries, credit amounts, credit duration, credit ceilings, minimum jobs required, and targeted jobholders. Some states target job credits toward specific locations. Kansas, for example, offers more for jobs created in nonmetropolitan areas. Georgia and Mississippi have a three-tier structure. Employment tax credits are also often part of the package of benefits available to firms that locate in enterprise, and more recently, empowerment zones.

The efficacy of JCTC, like most tax-abatement development strategies, remains hotly disputed. In an extensive examination of previous research, Bartik (1991) concedes that 
tax policy can have an effect on employment and wages, but that the effect is small. Wasylenko (1991) in a more recent comprehensive review is less sanguine. Findings regarding the effects of job tax credits are more favorable. Using survey methods, Pope and Kuhl (1996) found that small California firms would hire more workers if credits were available; at least that's what they said on the survey. Gabe and Kraybill (1999a and 1999b) use a survey of firms that announced major expansion projects in Ohio between 1993 and 1995, all of which were eligible for Ohio's JCTC. They concluded that the tax credit program had a positive impact on job creation and capital expansion in the state between 1993 and 1995. Katz (1996) found that the federal targeted tax credit program modestly improved the employment of young adults.

Research on the efficacy of enterprise zones is larger but less consistent (Bondonio 2000). In an analysis of Indiana enterprise zone program, Papke (1994) found that unemployment claims fell 19 percent in the year after an area was designated as an enterprise zone. Boarnet and Bogart (1995), however, found no such effects in an analysis of New Jersey's enterprise zone program. Greenbaum and Engberg (1998), in

an analysis of manufacturing firms, found positive employment effects on firms entering enterprise zones but negative effects on firms outside zones. These results suggest that enterprise zones perhaps may not increase total employment or economic activity, but can serve to alter their spatial distribution.

\section{Toward a Research Agenda}

The research reviewed above suggests that previous policy experiments offer considerable insight concerning how Maryland's smart growth programs might perform and how they should be evaluated.

Based on experience with UGBs, the critical questions concerning PFAs involve the extent to which they actually contain urban growth and whether such growth containment will cause land and housing price inflation. The best way to evaluate these effects is to establish a monitoring system that includes spatially specific data on land and housing 
prices and development activity. Further, because PFAs are designed to manage government spending, not actually urban development, spending by state and local governments should also be monitored.

Based on experience with TDR and PDR programs, the critical questions concerning the Rural Legacy program concerns the extent of activity in the market for development rights. Once again, the best way to evaluate these activities is to monitor the number and location of land development rights and sales. These are, however, input not output measures. A primary objective of the Rural Legacy program is to protect the agricultural economy and ecosystem health. Thus, a thorough evaluation of the success of the Rural Legacy program must include information about the health of the agricultural economy and the greater Chesapeake ecosystem.

Recognizing the experience of Brownfields programs in other states, the Brownfields program in Maryland should result in some brownfield redevelopment. Of course, this can be assessed by monitoring the number of sites that are redeveloped as part of the brownfield program. Once again, however, the objective of the brownfield program extends beyond the development of specific sites and involves the rehabilitation of existing urban areas. Thus, a more comprehensive evaluation strategy would involve monitoring the ratio of development in greenfields to development in brownfields.

Based on experience with JCTC in other states, the efficacy of Maryland's JCTC Program remains highly uncertain. Isolating the effects of particular economic development instruments is dicey. Local economies are influenced by so many factors that it is nearly impossible to isolate the effects of particular policy instruments. Of course it is possible to monitor the number of jobs for which tax credits are taken, the number of jobs eligible for tax credits, and the overall number of jobs. Information provided by such monitoring, however, will be limited. For the JCTC Program it may be best to note that credits are no longer available for firms that locate outside PFAs and simply claim success. 
Experience with redevelopment programs in other states offer little insight into the potential for the LNYW Program. There has never really been anything quite like it. Although all kinds of instruments have been used to revitalize inner city neighborhoods, there has never been a spatially targeted home-ownership subsidy program quite like Maryland's -- certainly none with the explicit goal of reducing travel to work. Despite the lack of antecedents, strategies for evaluating this program are simple and potentially quite interesting. Of course one again needs base information on individuals eligible for the program and individuals who participate. One can then explore differences in the location decisions and travel behaviors between the two groups. One can monitor home ownership rates inside and outside designated neighborhoods to see if significant differences arise. Analyses of these types will not only provide information about the efficacy of the LNYW program, but also new insights into fundamental questions concerning residential location and home ownership decisions.

In conclusion, Maryland's smart growth programs are indeed innovative but build on a long history of urban policy experiments. Based on the results of these experiments, there is reason to believe that each of the smart growth programs will have some degree of success. From a research perspective, each offers a new opportunity to conduct interesting research and gain new insights into the efficacy of urban growth management. 


\section{References}

\section{Smart Growth}

Burchell, R.W., D. Listokin, and C.C. Galley, 2000, Smart Growth: More Than a Ghost of Urban Policy Past, Less than a Bold New Horizon, Housing Policy Debate, 11,4:82180 .

Cohen, James, 2001, Maryland's Smart Growth: Using Incentives to Combat Sprawl. In Gregory Squires (ed.), Urban Sprawl: Causes, Consequences and Policy Responses, Washington, D.C.: Urban Institute Press.

DeGrove, J., forthcoming, The Shift to Smart Growth: State and Regional Systems for Managing Growth and Change, Cambridge, MA: Lincoln Institute of Land Policy.

Downs, Anthony. 2001, What Does "Smart Growth" Really Mean? Planning. April.

Nelson, Arthur C. 2001, How Do You Know Smart Growth When You See It? In Terry Szold, Armando Carbonelle, eds. Smart Growth: Form and Consequences, Cambridge, MA: MIT Press and Lincoln Institute of Land Policy (2001).

One Thousand Friends of Maryland, 2001, Smart Growth: How is Your County Doing, Baltimore, MD, 1000 Friends of Maryland.

\section{Priority Funding areas}

Benfield, F.Kaid, Matthew D. Raimi, and Donald D.T. Chen, 2001, Once There Were Greenfields: How Urban Sprawl is Undermining America's Environment, Economy, and Social Fabric, Washington, DC: Natural Resources Defense Council

Ding, Chengri, Gerrit J. Knaap, and Lewis Hopkins, 1999, Managing Urban Growth with Urban Growth Boundaries: A Theoretical Analysis, Journal of Urban Economics, 46:5368

Hopkins, Lewis, 2001, Urban Development: The Logic of Land Use Planning, Washington, D.C.: Island Press.

Knaap, Gerrit J., The Urban Growth Boundary in Metropolitan Portland, Oregon: Research, Rhetoric, and Reality, American Planning Association, PAS memo, 2001, available on line at http://www.multnomah.lib.or.us/metro/growth/ugbursa/apa_article.html

Knaap, Gerrit J. and Lewis Hopkins, 2001, The Inventory Approach to Urban Growth Boundaries, Journal of the American Planning Association, 67,3:314-326.. 
Knaap, Gerrit J., 1985, The Price Effects of Urban Growth Boundaries in Metropolitan Portland, Oregon, Land Economics, and 61,1:26-35.

Knaap, Gerrit J. and Arthur C. Nelson, The Regulated Landscape: Lessons on State Land Use Planning from Oregon, Cambridge, Massachusetts: The Lincoln Institute for Land Policy, 1992.

Maryland Department of Planning, on line, Priority Funding Areas, available at http://www.mdp.state.md.us/smartgrowth/smartpfa.htm

Nelson, Arthur C. 1986. Using Land Markets to Evaluate Urban Containment Programs. Journal of the American Planning Association. Spring:156-171.

Nelson, Arthur C. 1985. Demand, Segmentation, and Timing Effects of an Urban Containment Program on Urban Fringe Land Values. Urban Studies. 22:439-443.

Phillips, J. and E. Goodstein. 2000. Growth Management and Housing Prices: the Case of Portland, Oregon. Contemporary Economic Policy 18,3:334-344.

Staley, Samuel R. and Gerard C.S. Mildner, 1999, Urban Growth Boundaries and Housing Affordability: Lessons from Portland.

\section{Rural Legacy}

American Farmland Trust, 1997, Transfer of Development Rights: What Works? Northampton, MA: American Farmland Trust.

Bae, Christine, 2000, Transferable Development Rights, Papers and Proceedings of the International Workshop on Urban Growth Management Policies of Korea, Japan and USA, Seoul National University.

Cohen, James, 2001, Maryland's Smart Growth: Using Incentives to Combat Sprawl. In Gregory Squires (ed.), Urban Sprawl: Causes, Consequences and Policy Responses, Washington, D.C.: Urban Institute Press.

Daniels, Tom, 1999, When City and Country Collide: Managing Growth in the Metropolitan Fringe, Washington, D.C.: Island Press.

Henderson, Margaret, 1997, Transfer of Development Rights and Land Trusts: mechanisms to Preserve Open Space, MA Thesis, University of Texas at Austin.

Jacobs, Harvey, 1993, Transferable Development Rights Programs in the American Experience, unpublished, Department of Urban and Regional Planning, University of Wisconsin, Madison. 
Johnson, Robert and Mary Madison, 1997, From Landmarks to landscapes: A review of current practices in the transfer of development rights, Journal of the American Planning Association, 63,3:365-78.

Machemer, Patricia, 1998, Transferable Development Rights as a Growth Management

Technique in Landscape Management: A Case Study Approach, unpublished dissertation, Department of Resource Development, Michigan State University.

Maryland Department of Planning, on line, Rural Legacy, available at http://www.mdp.state.md.us/smartgrowth/legacy.htm

Single, Edward H., 1996, Transfer Development Rights and Land Use Planning in the United States, The Liverpool Law Review, 18,2: 147-166.

\section{Brownfield Redevelopment}

Anderson, Mark D., 1996, The State Voluntary Cleanup Program Alternative, NR\&E, Winter:22-26.

Bartsch, Charles and Bridget Dorfman, 2000, Brownfields and Housing: How are State VCPs Encouraging Residential Development? Chicago, IL: Northeast/Midwest Institute.

De Sousa, Christopher, 2000, Brownfield Redevelopment versus Greenfield Development: A Private Sector Perspective on the Costs and Risks Associations with Brownfield Redevelopment in the Greater Toronto Area, Journal of Environmental Planning and Management, 46,3:831-53.

Howland, Marie, 2000, The Impact of Contamination of the Canton/Southeast Baltimore Land Market, Journal of the American Planning Association, 66,4: 441-420.

Howeland, Marie, 2002, The Legacy of Contamination and the Redevelopment of InnerCity Industrial Districts, Unpublished manuscript, University of Maryland, College Park.

ICF Consulting, Inc. and E.P. Systems Group, Inc., 1999, Assessment of State Initiatives to Promote Redevelopment of Brownfields, prepared for the U.S.Department of Housing and Urban Development, Office of Policy Development and Research.

Leigh, Nancy Green, 1994, Focus: Environmental Constraints to Brownfield Redevelopment, Economic Development Quarterly, 8,4:325-328.

Maryland Department of Planning, on line, Brownfields, available at http://www.mdp.state.md.us/smartgrowth/brownfields.htm 
Meyer, Peter B. and Thomas Lyons, 2000, Lessons from Private Sector Brownfield Redevelopers: Planning Public Support for Urban Regeneration, Journal of the American Planning Association, 66,1:46-57.

Meyer, Peter B., Richard H. Williams, and Kristen R. Yount, 1995, Contaminated Land: Reclamation, Redevelopment and Reuse in the United States and the European Union, Aldershot, UK: Edward Elgar.

Simons, Robert A. and Donald T. Iannone, 1997, Brownfields: Supply and Demand, Urban Land, June 1997, 36-38.

\section{Live Near Your Work}

Haurin, Donald R., Robert D. Dietz, and Bruce A. Weinberg, 2002, The Impact of Neighborhood Homeownership Rates: A Review of the Theoretical and Empirical Literature, unpublished manuscript, Ohio State University.

Maryland Department of Planning, on line, Job Creation Tax Credit, available at http://www.mdp.state.md.us/smartgrowth/taxcredit.htm

Newman, S.J. and A.B. Schnare, 1992, Beyond Bricks and Mortar: Reexamining the Purpose and Effects of Housing Assistance, Washington, D.C.: Urban Institute Press.

Newman, S.J. and A.B. Schnare, 1997, And a Suitable Living Environment: The Failure of Housing Programs to Deliver on Neighborhood Quality, Housing Policy Debate, $8,4: 703-742$.

Rohe, W.M. and L.S. Stewert, 1996, Homeownership and Neighborhood Stability, Housing Policy Debate, 7,1:37-81.

Rohe, W.M., S. Van Zandt, and G. McCarthy, The Social Benefits and Costs of Homeownership: A Critical Assessment of the Research, Working Paper \#00-01, Research Institute of America, Washington, DC.

Rossi, P.H. and E. Weber, 1996, The Social Benefits of Homeownership: Empirical Evidence from National Surveys, Housing Policy Debate, 7,1:1-36.

Schwartz, A., 1999, New York City and Subsidized Housing; Impacts and Lessons of the City’s \$5 Billion Capital Budget Housing Plan, Housing Policy Debate, 10,4:839-878.

Simons, R.A. and D.S Sharkey, 1997, Jump-Starting Cleveland's New Urban Housing Markets: Do the Potential Fiscal Benefits Justify the Public Subsidy Costs? Housing Policy Debate, 8,1:143-172.

Temkin, K. and W. Rohe, 1996, Neighborhood change and Urban Policy, Journal of Planning Education and Research, 15:159-170. 
Van Ryzin, G.G. and A. Genn, 1999, Neighborhood Change and the City of New York's Ten-Year Housing Plan, Housing Policy Debate, 10,4:799-838.

Wilson, David and George Lentz, 1987, Residential Tax Incentives, Targeting Zones, and Equity, unpublished discussion paper, Indiana University, Indianapolis.

\section{Job Creation Tax Credits}

Bartik, Tim, 1991, Who Benefits from Economic Development Policy? Kalamazoo, MI: W.E. Upjohn Institute.

Bishop, John H. and Mark Montgomery, 1993, Does the targeted job tax credit create jobs at subsidized firms? Industrial Relations, 32, 3:243-52.

Boarnet, Marlon and William Bogart, 1995, Enterprise Zones and Employment: Evidence from New Jersey, Journal of Urban Economics, 40,2:198-215.

Bondonio, Daniele, 2000, Do Geographically-Targeted development Incentives

Revitalize communities? Evidence from the State Enterprise Zone Program, unpublished dissertation, Heinz School of Public Policy and Management, Carnegie Mellon University.

Brunori, David, 1997, Principles of tax policy and targeted tax incentives, State and Local Government Review, 29,1:50-61

Burtless, Gary, 1985, Are targeted wage subsidies harmful? Evidence from a wage voucher experiment, Industrial and Labor Relations Review, 39,1:105-114.

Carliner, M.S, 1998, Development of Federal Housing Policy, Housing Policy Debate, 9,2:299-322.

Faulk, Dagney Gail, 1999, An Analysis of the Participation Decision and Employment Impact of State Employment Tax Credits, unpublished dissertation, Andrew Young School of Policy Studies, Georgia State University.

Gabe, Todd, and David Kraybill, 1999a, Tax Incentives and Offers in a State Economic Development Program, Review of Regional Studies.

Gabe, Todd and David Kraybill, 1999b, The Effects of Tax Incentives on Enterprise Growth, Department of Agricultural, Environmental and Development Economics, The Ohio State University.

Gabe, Todd, 1996, Are tax incentives for economic development rational? Journal of Regional analysis and Policy, 26:87-100. 
Greenbaum, Robert and John Engberg, 1998, The Impact of Urban Enterprise Zones on Business Outcomes, Presented at the Southern Economic Association Annual Meetings, Baltimore, MD.

Katz, Lawrence, 1996, Wage Subsidies for the Disadvantage, National Bureau of Economic Research Working Paper 5679, Cambridge: NBER.

Ladd, Helen, 1998, Local government tax and land use policies in the United States, Northampton, MA: Edward Elgar.

Ladd, Helen, 1994, Spatially targeted development strategies: do they work? Cityscape, $1,1: 193-218$.

Maryland Department of Planning, on line, Live Near Your Work, available at http://www.mdp.state.md.us/smartgrowth/lnyw.htm

Papke, Leslie, 1994, Tax Policy and Urban Development Evidence from the Indiana Enterprise Zone Program, Journal of Public Economics, 45,1:47-68.

Pope, Ralph and James Kuhle, 1996, Tax credits for job creation and job retention in the California economy, Public finance Quarterly, 24,2:192-215.

Wasylenko, Michael, 1991, Taxation and Economic Development: The state of the economic literature, New England Economic Review, March/April.

Wasylenko, Michael, 1991, Empirical Evidence on interregional business location decisions and the role of fiscal incentives in economic development, in industry Location and public policy, eds., Henry Herzog, Jr. and Alan Schlottmann, 13-30, Knoxville, TN: Tennessee UP. 